\title{
The Application of Andragogy for the Advanced Diploma Program in Education at Saudi Arabia's Taif University
}

\author{
Obaidalah H. Aljohani, Taif University, Saudi Arabia \\ Sarah M. Alajlan, Taif University, Saudi Arabia
}

\begin{abstract}
This study's aim was to explore advanced diploma program students' perceptions about the application and importance of andragogy. The study also investigated if there is a difference, by gender, among the learners' point of view about the application and importance of andragogy to the learning environment. A self-administered questionnaire was utilized. The study population included all learners $(n=1,235)$ who were studying with Taif University's advanced diploma program in education. The study findings revealed that the importance of the five andragogical assumptions (motivation, experience, need to know, readiness to learn, and self-directedness) for the learners. There were statistically significant differences $(\alpha=0.05)$, due to gender, among the students' perceptions about the learners' need to know; these differences were seen for both the application and importance of the andragogical principles; the variations favored females. Therefore, teachers should employ learning strategies that encourage self-directed learning among students.
\end{abstract}

\section{KEYWORDS}

Advanced Diploma Program, Andragogy, Saudi Arabia, Taif University

\section{INTRODUCTION}

The traditional method of teaching is one of the challenges facing Saudi Arabia's educational system. This method is utilized for courses because of the teachers' poor preparation (Al-Harbi \& Al-Mahdi, 2016). This study was done in response to the need to improve teacher preparation. People who attend a teaching college are adults; therefore, they should be treated as adult learners. The fundamental premise for this paper is that, to improve teacher preparation, adult-learning strategies should be used in the classroom. In the present study, the authors report on the student perceptions about using adultlearning approaches in a classroom for the advanced diploma program in education at Saudi Arabia's Taif University. "Andragogy's core adult learning principles take the learner seriously" (Knowles, Holton III, \& Swanson, 2014, p. 183). The tenets of andragogy extend beyond simply valuing the student. Adult learners are the primary source of information when making decisions related to the learning process (Knowles et al., 2014). Techniques and teaching methods for young people should be different than the approaches utilized with adult learners (Knowles, 1990). Therefore, these differences should be considered when creating plans, orientations, and instructional methods.

Knowles (1980) suggested six assumptions about the characteristics of adult learners. These assumptions are self-concept, need to know, use of prior experience, readiness to learn, orientation to learn, and motivation to learn. Thus, this study presents the application and the importance of

\section{DOI: 10.4018/IJICTE.20210701.oa1}

\footnotetext{
This article, published as an Open Access article on April 23rd, 2021 in the gold Open Access journal, the International Journal of Information and Communication Technology Education (converted to gold Open Access January 1st, 2021), is distributed under the terms of the Creative Commons Attribution License (http://creativecommons.org/licenses/by/4.0/) which permits unrestricted use, distribution, and production in any medium, provided the author of the original work and original publication source are properly credited.
} 
these assumptions for adult-education theory with the advanced diploma program in education at Saudi Arabia's Taif University. The study also explores if there is a difference, by gender and among the learners' perceptions, about the application and importance of applying andragogy principles to the learning environment.

\section{BACKGROUND}

In Saudi Arabia, men, and women study in separate classrooms. Equal opportunities are afforded for men and women in the educational process, but there is gender segregation at Saudi universities. If there is a shortage of female instructors, a man teaches the women's course; he is in a different location and utilizes computer equipment which enables the women to see him while keeping them from his view (Aljohani \& Alajlan, 2020). The education system in Saudi Arabia includes about 30 public universities, 12 private universities, and many private colleges and institutes. The Saudi government provides free education in four stages: primary, intermediate, secondary, and university education. Students are given textbooks and transportation; there is also a stipend for university students and people enrolled at vocational institutes. The Saudi Arabian government has undertaken extensive educational policy reforms related to curricula, assessment, and professional development for teachers, with a continuous focus on learning outcomes at all levels. The government is also committed to the 2030 Agenda of the United Nations Educational, Cultural, and Scientific Organization (UNESCO) through the fourth goal of sustainable development in education (Saudi Vision 2030, 2015).

The Saudi government attaches great importance to the promotion of education in order to shape a generation with diverse cultures and a strong education. Accordingly, the country launched Saudi Vision 2030 to be the curriculum and a roadmap; this project focuses on an integrated package of programs in order to develop the educational environment through its various stages as well as its numerous approaches and methods. For example, one of the vision's aims is to prepare the teachers with professional development in order to meet the requirements of a 21 st-century teacher and to develop the instructors' skills as a way of keeping pace with the intellectual, knowledge, technological, and industrial developments (Saudi Vision 2030, 2015). Establishing the advanced diploma program in education came with Taif University's initiatives for the programmatic transformation project, an endeavor which coincides with Saudi Arabia's vision. The educational diploma program was based on a set of principles, the most prominent of which is the university's desire to be a pioneer to enhance the professionalism of teacher preparation with a vision that stems from studying and analyzing reality as well as anticipating the future (Taif University, 2018).

\section{The Advanced Diploma Program in Education}

In 2017, Taif University's advanced diploma program in education was started; the program was approved by the Ministry of Education. To clarify, Taif University is located in the city of Taif; the university was established in 2004 (Taif University, 2018). To create the advanced diploma program in education, Taif University officials had a vision that emanated from studying and analyzing reality as well as looking ahead. Taif University applied quality standards and academic accreditation to its advanced diploma program in education. In an effort to meet the teachers' needs, the university worked to study the reality for people in educational posts in order to identify the teachers' most important need as they improve their performance. Students who graduate from the program have the opportunity to complete a professional master's degree. The program has 38 credit hours which are divided into 3 semesters (Taif University, 2017).

According to Taif University (2017), the key program objectives include diversifying the teaching techniques to fit the adult learners and the diverse nature of the learning outcomes, contributing to the creation of stimulating and safe learning environments, identifying the psychological characteristics of learners and how to deal with adult learners, employing teaching methods that stimulate creativity 
among learners, and working on the learners' self-development as well as the implementing procedural research.

Therefore, the use of teaching methods that meet the learners' educational needs can support student learning and increase student success (Al-Harbi \& Al-Mahdi, 2016). The advanced diploma program in education was developed at Taif University. The program was designed to prepare qualified educational and vocational specialists who are capable of planning and implementing the educational process (Taif University, 2017).

In order to prepare qualified specialists, there must be sufficient knowledge about the tenets of adult learners' attributes which differentiate them from young learners. For example, adult learners' motivations are not the same as the young learners' reasons (Knowles, 1990). Therefore, preparing the adult learners in classrooms is important to achieve the program's goals. In Saudi Arabia, there has not been study about the importance of applying adult-education theory in the classroom. Adulteducation theory helps students to be self-educated and to have their own identities (Knowles et al., 2014), and this outcome is what Taif University is seeking to achieve with its advanced diploma program in education. The teaching profession is a great career, so it is necessary to effectively prepare teachers for success as well as to achieve the program's desired purpose. This study is designed to answer the following questions: What are the students' views about the application and importance of adult-education theory to the advanced diploma program in education at Taif University? Is there a statistically significant difference, based on gender, among the students' views about the application and importance of adult-education theory to the advanced diploma program in education at Taif University?

\section{Rationale}

This study is significant for the field of adult education because knowing about a learner's experiences regarding the application and importance of using the andragogy principles helps the instructors to prepare more meaningful lessons. The study may provide helpful information for Saudi Arabia's decision makers regarding the weaknesses which stand in the way of achieving the program's objectives. Moreover, identifying the program's strengths in order to enhance and to improve it will enable it to reach a higher quality. Additionally, future programs will benefit from this study's results.

\section{THEORETICAL FRAMEWORK}

As people mature, they need teaching methods which are appropriate for them as adult learners; the instruction methods also need to consider people's needs and psychological characteristics. Therefore, the study's theoretical framework came from the theory of andragogy and its six principles: the learners' need to know, self-concept, prior experience, readiness to learn, orientation to learn, and motivation to learn (Knowles, 1980). These principles provide a framework about how and why adults learn. The six principles of andragogy are consistent with what Muslim scholars advocated a thousand years ago. For example, Al-Ghazali and Ibn Khaldun, Muslim philosophers, believed that children's thinking differs significantly from adults' thinking; therefore, teachers must take these variations into account when instructing students (Metwally, 2004). Burhan ad-Din, a Muslim thinker wrote many books about education, such as the Methods of Self Learning. He believed that having teachers pose questions and share experiences with their students is more beneficial than sheer repetition (Ahmad, 1989). Al-Khalidi (2011) stated that, at the beginning of Islam, teachers emphasized how effective learning depends on the learners' willingness, interest, and motivation to engage in the classroom. The andragogy theory was chosen because it is compatible with the Arab and Islamic environment. Andragogy is also compatible with the objectives of this research paper that studies how adults learn. The target population for this study is adult learners. 


\section{Andragogy}

Andragogy is a set of practices which are centered on the learner. The term "andragogy" is derived from the Greek root "ander" meaning man, or adult and the word "agogus" which means leading or teaching. Andragogy was originally introduced by Alexander Kapp, a German teacher, in 1833 (Knowles, 1990) and then evolved into a theory called adult education by Malcolm Knowles, an American educator. Knowles (1968) proposed andragogy as "a new label and a new technology" (p.351), distinguishing adult learning from children's learning or pedagogy. Andragogy is "the art and science of helping adult learn" (Knowles, 1980, p. 43). The andragogy approach is based on a special view of adult learners. According to Knowles (1990), adults learn by application and participation. Therefore, the adults' best learning occurs when they are involved with the learning strategies. For example, educators, as facilitators, should encourage students to take the reins towards knowledge acquisition away from the traditional teaching that presents ready-made information. Andragogy is based on a set of assumptions that must be available in the adult learners' personality. These assumptions provide a framework for understanding how and why adults learn.

\section{The Learners' Need to Know}

Adults want to know the reason to learn something before learning it (Knowles et al., 2014). Engaging adults in the learning process satisfies their need to gain knowledge; this involvement also raises awareness about people's reason for learning, enabling learners to see the benefits of knowing what they want to learn (Knowles, 1980). Therefore, adult learners should realize the instructional content's worth before engaging in learning and should connect the material's importance to their lives (Hinkson, 2010).

\section{The Learners' Self-Concept}

Adult learners have the independence and the ability to express opinions and criticism. "As a person matures, they become more independent and self-directing, in fact speaks to the self-directed nature of adult learners" (Merriam, 2017, p. 24). Merriam, Caffarella, and Baumgartner (2007) describe selfdirected learning as "a process of learning in which people take the primary initiative for planning, carrying out, and evaluating their own learning experiences" (p.110). Self-directed learning does not mean that an adult sits in a classroom alone. It is about how the students take control of their own learning. To illustrate, people can enjoy a class, find a mentor, or join an online discussion group (Merriam, 2017). According to Knowles (1990), the most successful self-directed learners are highly skilled at getting support from peers, teachers, printed materials, audiovisual aids, and any other type of resources. Knowles et al. (2014) state that self-directed learning is a method that can improve education; therefore, adult learners should practice self-directed learning by setting their goals and learning purposes as well as selecting learning methods in order to evaluate their progress rather than relying on the instructor for all information (Brookfield, 1995).

\section{The Learners' Prior Experience}

Adult learners have typically gathered and developed more life experiences that could help individuals to learn in the classroom. When people's knowledge and skills are diminished or are not utilized, the individuals believe that they and their skills have been snubbed (Knowles, 1980). With adult learners, the students' involvement and the instructor's wisdom are equally important (Knowles et al., 2014). According to Knowles (1980), the adult-education facilitator must create a learning environment, such as group discussion, problem-solving exercises, and collaborative assignments, that can help adult learners benefit from their experience by drawing on the heterogeneity and expertise within groups. 


\section{The Learners' Readiness to Learn}

Within the pedagogical framework, the concept of readiness to learn is defined as the learners doing what is necessary to meet the success criteria specified by the teacher and the course syllabus (Ferreira, MacLean, \& Center, 2018). As people mature, they have the desire to learn about subjects that are directly related to their work or their real-life situations (Knowles et al., 2014). Pratt (1988) proposed a useful model about how to influence the positions of adults' lives for their readiness to learn. Students have different attitudes about learning. Some people need guidance to be selfdirected. Other individuals have confidence and are self-reliant with learning. Therefore, teachers, as facilitators, should react with the learners in order to help when students need assistance to promote the educational experience.

\section{The Learners' Orientation to Learn}

Adults focus on direct applications, rather than future uses, of their learning. Adult learners have a tendency towards learning that is problem-centered; task-oriented; and about real-life situations, not subjects. Therefore, "learning experiences should be organized around competency-development categories. People are performance-centered in their orientation to learning" (Knowles, 1980, p.44). Teaching strategies should focus on applying what is learned to solve real-life problems (Hinkson, 2010).

\section{The Learners' Motivation to Learn}

"Motivation for learning is that compulsion which keeps a person in the learning situation and encourages them to learn" (Rogers \& Horrocks, 2010, p.105). Knowles et al. (2014) strongly believed that the adults' motivation is internal (self-esteem and self-actualization) rather than external (better jobs and promotions). These finding do not mean that external motivation does not engage adults, but the most potent incentives for adults to learn are internal pressures. Therefore, the teacher should understand the learners' need as well as appreciating and respecting their needs in order to create an environment that is conducive to learning. Promoting learners' self-respect by acknowledging their role for contributing to the class will further encourage learners to succeed with their coursework (Blondy, 2007).

\section{METHODOLOGY}

\section{Population and Sample}

Taif University's deputy dean for the education faculty provided a list of students who were studying with the advanced diploma program in education in 2018; those students were the target population for this research. The study's total population was 1,235 (409 males and 826 females). After a brief introduction about the purpose of the study, the benefits of the study, and ensured confidentiality, respondents were asked to complete the questionnaire through the mail and social media (WhatsApp). The study was conducted during the Spring 2018 semester: 526 students (171males and 355 females) participated, and the sample is described in Table 1.

\section{Instrument}

The data for this study were gathered by utilizing a self-administered questionnaire. The instrument was designed to identify the learners' perceptions regarding the application and importance of using Malcolm Knowles' six principles of andragogy in the classroom. This questionnaire had two parts. The first part consisted of demographic information (female or male). The second part included the 21 andragogical assumptions (motivation, prior experience, need to know, readiness to learn, and self-directedness). These items used a 5-point Likert scale (strongly agree $=5$, agree $=4$, either agree or disagree $=3$, disagree $=2$, and strongly disagree $=1$ ) to describes the learners' practices about the 
Table 1. Number of Learners in the Higher Diploma Program in Education Who Participated in this Study (by Gender) in 2018

\begin{tabular}{|l|l|l|l|}
\hline & & Frequency & \multicolumn{1}{c|}{ Percentage } \\
\hline Sex & Male & 171 & 32.5 \\
\hline & Female & 355 & 67.5 \\
\hline & Total & 526 & 100.0 \\
\hline
\end{tabular}

application of andragogy assumptions in their classroom. Also, a 5-point Likert scale (very important $=5$, important $=4$, somewhat important $=3$, not important $=2$, and not at all important $=1$ ) was utilized to identify the most important practices for the learners.

The questionnaire was developed by Wilson (2005) who tested the instrument's reliability and validity. The final version of the questionnaire contained five andragogical assumptions: (a) The learners' motivation reliability was $\alpha=.933$; (b) the learners' prior-experience reliability was $\alpha=$ .839 ; (c) the need-to-know reliability was $\alpha=.760$; (d) the readiness-to-learn reliability was $\alpha=.811$; and (e) the self-directedness reliability was $\alpha=.739$.

\section{Reliability and Validity}

Because the participants native Arabic speakers, the instrument was translated into Arabic by individuals who had mastered the Arabic and English languages in order to ensure that the survey asked equivalent questions in each language. The instrument was then translated back into English. University professors reviewed the instrument. The pilot test was conducted with 14 participants who had characteristics similar to the study participants in order to obtain feedback about the accuracy and ease of understanding the instrument. An estimate of the Cronbach's alpha was .979, which indicted high reliability for the survey questions.

\section{Findings for Research Question One}

Descriptive analysis, including mean and standard deviations, is utilized to present the students' views about the application of andragogy for the advanced diploma program in education at Saudi Arabia's Taif University as well as to understand the students' views about the importance of Knowles' theory of andragogy. According to the data in Table 2, the students' views about the application of the andragogical assumptions show that the means ranged between 3.34 and 3.89. "Need to know" was the highest-ranked factor that students practiced in their classroom; that item had a mean of 3.89. "Readiness to learn" was the lowest-ranked factor that students practiced in their classroom. The mean for that factor was 3.34. Overall, the respondents were positive about the five assumptions.

For the students' perceptions about the importance of the andragogy assumptions, the results show that the means ranged between 4.05 and 4.29. "Readiness to learn" was the most important andragogical assumption for participation; that item had a mean of 4.29. On the other hand, "experience" was last, having a mean of 4.05. Table 3 shows the means and standard deviations for the importance of the andragogical assumptions.

\section{Findings for Research Question Two}

A T-test was conducted to discover if there were a statistically significant difference among the responses, based on the gender variables, for the students' views about the application and importance of the andragogy principles for the advanced diploma program in education. For the application of the andragogical principles, the T-Test was statistically significant $(\alpha=0.05)$. Therefore, there were significant differences for the learners' need to know that favored females. For the importance of the andragogical principles, the T-Test was statistically significant $(\alpha=0.05)$. There were only significant differences for the learners' "need to know." The benefit of the direction was for females. 
Table 2. The Mean and Standard Deviation for the Application of the Andragogical Principles

\begin{tabular}{|l|l|l|l|l|}
\hline Rank \# & \multicolumn{1}{|c|}{ Andragogical Assumptions } & \multicolumn{1}{c|}{ Mean } & \multicolumn{1}{c|}{ Std. D. } & \multicolumn{1}{c|}{ Level } \\
\hline 3 & Motivation & 3.69 & .993 & 1 \\
\hline 2 & Experience & 3.74 & .951 & 2 \\
\hline 1 & Need to Know & 3.89 & 1.010 & 3 \\
\hline 5 & Readiness to Learn & 3.34 & 1.056 & 4 \\
\hline 4 & Self-Directedness & 3.62 & 1.179 & 5 \\
\hline & Total Score & 3.68 & .920 & \\
\hline
\end{tabular}

\section{DISCUSSION}

In terms of applying the andragogical principles, the study's findings confirmed that the respondents practiced the andragogical assumptions (motivation, experience, need to know, readiness to learn, and self-directedness) in the classroom. These findings agreed with the objectives for Taif University's advanced diploma program in education. For example, some objectives provided teaching methods that fit with the nature of adult learners and enhanced the learners' self-development.

Need to know obtained the highest mean for the methods practiced in the classroom. Most survey participants reported that they understood why they needed to participate in this learning experience. This study's result agreed with Hinkson's (2010) findings. Hinkson indicated that the highest-ranked preference reflected Knowles' principle the need to know. Adults have strong emotions about the reason to learn something before studying it. Therefore, knowing why adults need to learn something is the key to giving them a desire for learning (Knowles et al., 2014). In the Holy Quran, one statement is as follows: "And do not pursue that of which you have no knowledge. Indeed, the hearing, the sight and the heart about all those [one] will be questioned" (Quran, n.d., al-Isra, Verse 36, p. 200). This verse emphasizes that people should not follow something about which they have no knowledge.

The assumption about experience had the second-highest mean for activities which students practiced in Taif University's classrooms for the advanced diploma program in education. Adult learners come to educational situations with diverse experiences that can enrich the learning of new information (Kasworm, 2003). To improve the learners' experiences, the instructors should help students to share their opinions regarding the classroom activities. Therefore, the instructor, as a facilitator, should organize the course to enhance the participants' sharing of experiences through the use of group projects and interactive discussions (Blondy, 2007). According to Harper and Ross (2011), when students have the chance to contribute to and participate in their studies, they have more motivation and engagement when learning.

Table 3. The Mean and Standard Deviation for the Importance of the Andragogical Assumptions

\begin{tabular}{|l|l|l|l|l|}
\hline \multicolumn{1}{|c|}{ Rank \# } & \multicolumn{1}{|c|}{ Andragogical Assumptions } & \multicolumn{1}{c|}{ Mean } & \multicolumn{1}{c|}{ Std. D. } & \multicolumn{1}{c|}{ Level } \\
\hline 3 & Motivation & 4.26 & .552 & 1 \\
\hline 5 & Experience & 4.05 & .681 & 2 \\
\hline 4 & Need to Know & 4.17 & .590 & 3 \\
\hline 1 & Readiness to Learn & 4.29 & .641 & 4 \\
\hline 2 & Self-Directedness & 4.28 & .657 & 5 \\
\hline & Total Score & 4.22 & .516 & \\
\hline
\end{tabular}


On the other hand, this research revealed that readiness to learn and self-directedness had the lowest means for the methods that students practiced in the program's classroom. Despite the remarkable development at Saudi universities, some instructors were still using traditional teaching methods that depended on rote memorization. Al-Harbi and Al-Mahdi (2016) stated that the one of the challenges facing Saudi Arabia's educational systems was the teacher's traditional technique based on repetition; this method was used because of weak teacher preparation at some colleges. According to Knowles (1995), the instructor should allow students to practice self-directed learning instead of relying on the instructor for their education. Learning should build on the students' experience and should be based on a welcoming and collaborative environment.

For the second part about the importance of andragogical principles, the results demonstrated that Knowles' principles of andragogy were extremely important because the learners, as students, practiced teaching in the classrooms. Leigh, Whitted, and Hamilton (2015) pointed out that the six andragogy principles were beneficial at all learning stages, including formal and informal learning as well as specialized learning. Readiness to learn received the highest mean, followed by self-Directedness, regarding the degree of importance. Perhaps this finding illustrated that respondents do not have enough opportunities to practice self-directed learning and readiness to learn in the classroom because self-directedness and readiness to learn received the lowest mean for the practice of andragogical assumptions section. Therefore, respondents saw these two assumptions as having more importance than the other andragogical assumptions. This result may be because students do not practice other methods in the classroom. According to Knowles et al. (2014), students are ready to learn information that they need in order to cope with their real-life problems. Blondy (2007) pointed out that instructors must address the students' needs at the beginning of the course in order to provide effective learning. Instructors can have a better understanding about the learners' readiness by posing questions to the class and requiring students to discuss their experiences with their peers. Instructors should allow time for the students to gather their thoughts before sharing them in class. Providing answers can help the instructors to obtain a better understanding about the students' readiness to learn the course content as well as allowing the students to have an enhanced grasp of what they are about to learn.

On the other hand, experience received the lowest mean regarding the degree of importance. Knowles (1980) indicated that sharing the learners' experience is very important to enhance and to enrich the learning environment. Wilson (2005) pointed out that experience can enhance or hinder the learning based on pre-determined expectations about what education should look and feel like. "When adults find themselves in situation in which their experience is not being used, or it's minimized, it is not just their experience that is being rejected - they feel rejected as persons" (Knowles, 1980, p.50). Therefore, teaching methods based on class discussions, peer groups, problem-solving exercises, and other experiential activities can enhance adult learning (Knowles et al., 2014). In addition, "a useful activity for sharing past experiences involves reflections from a journal" (Cochran \& Brown, 2016, p. 78).

The second question showed that, for the application and importance of andragogical principles, there were no statistically significant differences with motivation, experience, readiness to learn, and self-directedness based on gender. This result indicated that both male and female students had the same educational opportunities and learned the same material; additionally, all students were simultaneously exposed to identical experiences.

However, the question showed that, for the application and importance of andragogical principles, the only significant differences, due to gender, for the learners' need to know favored females. This result was rational because, with Saudi Vision 2030, Saudi women became more ambitious. Saudi Vision 2030 created more opportunities for women to work in various sectors. Saudi women now have ambitious reasons, for example, gaining leadership positions, to learn. Empowering women in Saudi Arabia is one of Saudi Vision 2030's goals (Saudi Vision 2030, 2015). 


\section{CONCLUSION AND IMPLICATIONS}

The power of adult-education theory lies in the basic assumption that adults have great motivations to learn which differ from the youths' reasons to learn. Adults need to know and to understand, which is directly reflected in the development of their social, economic, and professional conditions (Knowles et al., 2014). Saudi Vision 2030 also seeks to improve teaching methods that create a student-centered learning environment and to motivate teachers by affording an appropriate strategy in the classroom. This environment may help learners to be ambitious and able to compete and produce. According to Cochran and Brown (2016), instructors who understand the andragogical assumptions can apply them when developing courses, as well as student assignments and activities, in order to improve the learning environment.

Moreover, adults have a deep need for self-direction and have the ability to identify their needs and interests. Adults have accumulated life experiences and knowledge, along with skill development, that reinforce the learning experience (Knowles et al., 2014). In the Holy Quran, one verse stated, "Do they not look at the camels how they are created? And at the sky how it is raised? And at the mountains how they are installed?" (Quran, n.d., Al-Ghashiya, Verse 88, p. 17). This verse encourages people to be self-directed learners by thinking and meditating. Therefore, this study aims to discover the application and the importance of the assumptions for adult-education theory to Taif University's advanced diploma program in education. The study's results confirmed that learners practiced the five andragogical assumptions and that learners showed the importance of using the andragogical assumptions in the classroom. This result agreed with Saudi Vision 2030 and the diploma program's goals for education. However, there were statistically significant differences, due to gender, among the learners' perceptions about their need to know for both the application and importance of the andragogical principles; the variations favored females. This statement confirmed that the percentage of Saudi women who seek knowledge is continually increasing (The General Authority for Statistics, 2017).

Based on the study's results, self-directed learning was the assumption that learners practiced the least in the classroom. Also, it received less importance compare to the other assumptions. Therefore, instructors should understand how to apply the andragogical assumptions, especially self-directed learning, when they develop their courses in order to effectively deal with their students (Cochran \& Brown, 2016). For example, using the learning by investigation and discovery method, an instructor posts a problem and then asks the students to solve it, individually or as a group, by using the available materials, such as technology, reading, researching, and questioning. 


\section{REFERENCES}

Ahmad, M. (1989). Ta'alim al-Muta'allim [The instruction of the learner: Method of learning]. Maktabat AnNahda.

Al-Harbi, G., \& Al-Mahdi, Y. (2016). Nedam altaleem be almmlkah alarbeha alsaudiha: Alwaga wa almamwol [Education system in Saudi Arabia: Reality and hope]. Maktabat Al-Rushd.

Aljohani, O. H., \& Alajlan, S. M. (2020). Motivating Adult Learners to Learn at Adult-Education Schools in Saudi Arabia. Adult Learning, 31(4), 150-160. Advance online publication. doi:10.1177/1045159519899655

Al-Khalidi, K. (2011). Education and methods of teaching in Islam in the era of Az-Zarnooji. Al-Qasmi Arabic Language Academy, 4, 23-60.

Blondy, L. (2007). Evaluation and application of andragogical assumptions to the adult online learning environment. Journal of Interactive Online Learning, 6(2), 116-129.

Brookfield, S. D. (1995). Adult learning: An overview. In A. Tuinjman (Ed.), International encyclopedia of education. Pergamon Press.

Cochran, C., \& Brown, S. (2016). Andragogy and the adult Learner. In K. A. Flores, K. D. Kirstein, C. E. Schieber, \& S. G. Olswang (Eds.), Supporting the success of adult and online students (pp. 73-84). CreateSpace Independent Publishing Platform.

Ferreira, D., MacLean, G., \& Center, G. E. (2018). Andragogy in the 21st century: Applying the assumptions of adult learning online. ICU Language Research Bulletin, 32, 10-19.

General Authority for Statistics. (2017). Employment and wages survey. https://www.stats.gov.sa/

Harper, L., \& Ross, J. (2011). An application of Knowles' theories of adult education to an undergraduate interdisciplinary studies degree program. The Journal of Continuing Higher Education, 59(3), 161-166. doi:1 $0.1080 / 07377363.2011 .614887$

Hinkson, C. (2010). Community college graduates' perceptions of adult learning instructional practices employed in continuing education programs (Doctoral dissertation). Available from ProQuest Dissertations and Theses database. (UMI No. 3470192)

Kasworm, C. (2003). Adult meaning making in the undergraduate classroom. Adult Education Quarterly, 53(2), 81-98. doi:10.1177/0741713602238905

Knowles, M. (1968). Andragogy, not pedagogy. Adult Leadership, 16(10), 350-352, 386.

Knowles, M. (1980). The modern practice of adult education: From pedagogy to andragogy (2nd ed.). Cambridge Books.

Knowles, M. (1990). The adult learner: A neglected species (4th ed.). Gulf Publishing Company.

Knowles, M. S. (1995). Designs for adult learning: Practical resources, exercises, and course outlines from the father of adult learning. American Society for Training and Development.

Knowles, M. S., Holton, E. F. III, \& Swanson, R. A. (2014). The adult learner: The definitive classic in adult education and human resource development (8th ed.). Routledge.

Leigh, K., Whitted, K., \& Hamilton, B. (2015). Integration of andragogy into preceptorship. Journal of Adult Education, 42(1), 9-17.

Merriam, S. (2017). Adult learning theory: Avluation and future directions. Journal of Lifelong Learning, 26, 21-37.

Merriam, S. B., Caffarella, R. S., \& Baumgartner, L. M. (2007). Learning in adulthood: A comprehensive guide (3rd ed.). Jossey-Bass.

Metwally, M. (2004). Mdkl ela tareek altrbyah aleslamyah [Introduction to the history of Islamic education]. Dar Al-Khuraiji. 
Pratt, D. D. (1988). Andragogy as a relational construct. Adult Education Quarterly, 38(3), 160-181. doi:10.1177/0001848188038003004

Rogers, A., \& Horrocks, N. (2010). Teaching adults (4th ed.). Open University Press.

Saudi Vision 2030. (2015). An ambitious nation. Retrieved from https://vision2030.gov.sa/en/themes/4

Taif University. (2017). Advanced diploma program in education. Retrieved from https://www.tu.edu.sa/En/ Colleges/94/College-of-Education

Taif University. (2018). About TU. Retrieved from https://www.tu.edu.sa/AboutUs/

Wilson, L. S. (2005). A test of andragogy in a post- secondary educational setting (Doctoral dissertation, Louisiana State University). Available from ProQuest Dissertations and Theses database. (UMI No. 06152005-122402)

Obaidalah H. Aljohani, $\mathrm{PhD}$, is an assistant professor in the department of leadership and educational policies at Taif University in Saudi Arabia. His areas of research interest are andragogy, comparative and adult education, transformative learning theory, and lifelong learning.

Sarah Alajlan $(P h D)$ is an Assistant Professor for the School of Education in the Department of Leadership and Educational Policies at Taif University. 